\title{
Actionable Ideas to Improve Health Care and Health
}

\author{
Kurt C. Stange, $M D, P b D$, Editor \\ Ann Fam Med 2010;8:82-84. doi:10.1370/afm.1079.
}

$\mathrm{T}$ he Annals online discussion since the last issue addressed policy, practice, and education. Several actionable ideas pop out:

- Doing training in community health centers can meet the needs of the population.

- Linking practice and community can help change intractable health behaviors.

- Focusing pay-for performance on high-yield items is win-win

- Providing full-scope services to patients represents added value.

- Reform in practice systems and health care system may reduce inequalities.

- There is a potentially better test for peripheral neuropathy.

- Generalist understanding can guide action.

\section{DOING TRAINING IN COMMUNITY HEALTH CENTERS CAN MEET THE NEEDS OF THE POPULATION}

Carl Morris and Frederick Chen's study of training residents in community health centers ${ }^{1}$ caused readers to jump on this approach as a solution to many current health care system and training program ills. ${ }^{2}$

Candice Chen says:

Teaching Health Centers are an important step towards establishing a graduate medical education system responsive to the health care workforce needs of the nation.... Community Health Center-Family Medicine Residency partnerships, or Teaching Health Centers, are an intelligent step towards changing the current graduate medical education system-establishing residency programs with a health center base instead of a hospital base. Residents trained in these partnerships will be ready to work in [the] patient-centered medical home, multidisciplinary primary care practices and, as a previous study by Dr Morris and Dr Chen shows, these residents are more likely to practice in underserved settings. ${ }^{3}$

Maples notes that "we need family medicine residencies to be a pipeline, not a bottleneck," and that this pipe- line potential is supported by "community and migrant health care centers, and their proven ability to respond efficiently and effectively to national health priorities." ${ }^{14}$

Zeifler observes that the 4 themes identified by Morris and Chen (mission, money, quality, and administrative/governance complexity) represent both the challenges and the opportunities of training in community health centers. ${ }^{5}$

\section{LINKING PRACTICE AND COMMUNITY CAN HELP CHANGE INTRACTABLE HEALTH BEHAVIORS}

In the previous issue, Ferrer et al reported a clinical trial on the effect of engaging medical assistants in promoting health behavior change. ${ }^{6}$ Kottke and Pronc cite evidence that,

Because these behaviors are responsible for about half of all deaths in the United States, and because more than $80 \%$ of all health care costs for Americans are delivered to patients who have preventable chronic conditions, success would transform the health and health economics of our patients and our communities. ${ }^{7}$

Kottke and Pronc go on to observe a transformative opportunity:

...that, as are clinical services, the resources that are currently available in a community are no match for the physical and social environment that promotes unhealthy behaviors. New approaches are needed to help patients adopt healthy lifestyles. We suggest that partnerships between primary care practices and worksite-based health promotion programs might meet this need. ${ }^{7}$

In considering the implications of the study by Mainous et al, ${ }^{8}$ Gonzales, Corbett, and Morales cite the need to move beyond even community interventions to cross-national, multilevel efforts to reduce antibiotic resistance by diminishing the commercial availability of antibiotics. ${ }^{9}$ 


\section{FOCUSING PAY-FOR-PERFORMANCE ON HIGH-YIELD ITEMS IS WIN-WIN}

In response to a study documenting the costs to primary care practices of responding to payer requests for quality and performance data, ${ }_{1}^{10}$ Brantes, the CEO of Bridges to Excellence, observes,

The current focus of many quality reporting and improvement efforts tend to be on measures that have only a distant relationship to lowering cost or improving patient outcomes. As a result, the amounts that payers are willing to offer as a benefit to a practice for participating in the effort are relatively small, and this level of benefit is often lower than the cost of participation for the practice. ${ }^{11}$

Warburton ${ }^{12}$ and Bagley ${ }^{13}$ make similar points. Bagley says: "If the cost of organizing that information in a systematic way is balanced against the increased efficiency of the physician-patient encounter, it should be a clear win for all."

\section{PROVIDING FULL-SCOPE SERVICES TO PATIENTS REPRESENTS ADDED VALUE}

Multiple discussants cited the wisdom of making early abortion available within the context of ongoing care in a family medicine practice. ${ }^{14}$ In response, the study's lead author replies:

By providing more comprehensive reproductive health care we are able to provide preventive care services that cannot be as well delivered outside of the context of a medical home. The best example is our very high use of highly effective contraception (IUD and Implanon) post abortion which is not seen at sites that do not have continuity of care with their patients. More work is needed to show that it is really the continuity of care that matters but it sure feels like it does as we work with a woman/couple to consider what post abortion contraception steps will help her avoid ending up with another unintended pregnancy.

This preventive care model is a perfect fit for a specialty that feels comfortable with pregnancy care, has a tradition of offering medical procedures, emphasizes prevention and behavior change, values continuity of care, and loathes abandoning patients just when they have a health crisis. ${ }^{15,16}$

\section{REFORM IN PRACTICE SYSTEMS AND HEALTH CARE SYSTEM MAY REDUCE INEQUALITIES}

Dowling ${ }^{17}$ notes that multiple practice-level initiatives (shown by Zimmerman et al to be possible ${ }^{18}$ ) can help to reduce immunization disparities. He quotes a patient to support the need for sustained, multifactorial effort, since the problem is one result of "a whole lifetime of poor access to healthcare."
Considering the health care system fragmentation studied by DeVoe et al in the last issue, ${ }^{19}$ Guendelman implores: "It is of the essence that we remind policymakers of the benefits of streamlining health insurance so that children and their parents can navigate through the same health plans." 20

\section{THERE IS A POTENTIALLY BETTER TEST FOR PERIPHERAL NEUROPATHY}

Oyer cites his own research on the "Clanging Tuning Fork Test ${ }^{\prime 21}$ that apparently has greater sensitivity for picking up early loss of sensation than the more commonly advocated monofilament testing that was the subject of a meta-analysis by Dros and colleagues. ${ }^{22}$

\section{GENERALIST UNDERSTANDING CAN GUIDE ACTION}

Scherger ${ }^{23}$ and Green ${ }^{24}$ note the need to advance the intellectual basis of family medicine and solve intractable problems in health care and health by investigating the paradox of primary care. ${ }^{25}$

At the same time, Mackenzie ${ }^{26}$ and Katerndahl27 challenge the notion in the latest article in the ongoing editorial series ${ }^{28}$ that different levels of care represent holons within a holarchy. Rather than the levels of care being holons (wholes that are simultaneously parts of something else) that are hierarchically organized (into holarchies), Mackenzie asserts a different hierarchy:

The holons are the patient holon (which is part of the patient/health worker holon which is part of the organisational holon, community, society, nation, culture, civilisation, planet and so on, going down the patient holarchy would see a organ or disease holon as part of the patient, and cellular processes as parts of the disease holon, etc).

So all the levels of healthcare can be seen as concentric rings with fundamental care at the core and that all these levels of care can be mapped onto all the holons described above. $^{26}$

Please join the discussion at http://www. AnnFamMed.org.

\section{References}

1. Morris CG, Chen FM. Training residents in community health centers: facilitators and barriers. Ann Fam Med. 2009;7(6):488-494.

2. TRACK discussion in response to: Morris CG, Chen FM. Training residents in community health centers: facilitators and barriers. Ann Fam Med. 2009;7(6):488-494. http://www.annfammed.org/cgi/eletters/7/6/488. Accessed Nov 30, 2009.

3. Chen CP. An important step towards revitalizing primary care [eletter]. http://www.annfammed.org/cgi/eletters/7/6/488\#11366, 11 Nov 2009.

4. Maples W. The right message, and the right time [eletter]. http:// www.annfammed.org/cgi/eletters/7/6/488\#11370, 12 Nov 2009. 
5. Zeifler JA. CHC-FMRs: Achieving synergy in mission, money, quality, and complexity [eletter]. http://www.annfammed.org/cgi/eletters/7/6/488\#11368, 11 Nov 2009.

6. Ferrer RL, Mody-Bailey P, Jaén CR, Gott S, Araujo S. A medical assistant-based program to promote healthy behaviors in primary care. Ann Fam Med. 2009;7(6):504-512.

7. Kottke TE, Pronk NP. A primary care-worksite health promotion collaboration might facilitate behavior change [eletter]. http://www. annfammed.org/cgi/eletters/7/6/504\#11387, 17 Nov 2009.

8. Mainous III AG, Diaz VA, Carnemolla M. A community intervention to decrease antibiotics used for self-medication among Latino adults. Ann Fam Med. 2009;7(6):520-526.

9. Gonzales R, Corbett K, Morales HR. Time for a multinational campaign to control antibiotic resistance [eletter]? http://www. annfammed.org/cgi/eletters/7/6/520\#11412, 24 Nov 2009.

10. Halladay JR, Stearns SC, Wroth T, et al. Cost to primary care practices of responding to payer requests for quality and performance data. Ann Fam Med. 2009;7(6):495-503.

11. de Brantes F. The juice can be worth the squeeze [eletter]. http:// www.annfammed.org/cgi/eletters/7/6/495\#11362, 11 Nov 2009.

12. Warburton SW. No free lunch [eletter]. http://www.annfammed. org/cgi/eletters/7/6/495\#11380, 16 Nov 2009.

13. Bagley B. What price quality [eletter]? http://www.annfammed.org/ cgi/eletters/7/6/495\#11359, 11 Nov 2009.

14. TRACK discussion in response to: Bennett IM, Baylson M, Kalkstein K, Gillespie G, Bellamy SL, Fleischman J. Early abortion in family medicine: clinical outcomes. Ann Fam Med. 2009;7(6):527-533. http:// www.annfammed.org/cgi/eletters/7/6/527. Accessed Nov 30, 2009.

15. Bennett IM. Response to Chavkin [eletter]. http://www.annfammed. org/cgi/eletters/7/6/527\#11407, 23 Nov 2009

16. Bennett IM. Response to Greenburg [eletter]. http://www. annfammed.org/cgi/eletters/7/6/527\#11409, 23 Nov 2009

17. Dowling PT. Vaccines, race and disparities [eletter]. http://www. annfammed.org/cgi/eletters/7/6/534\#11372, 12 Nov 2009
18. Zimmerman RK, Nowalk MP, Tabbarah M, Hart JA, Fox DE, Raymund $\mathrm{M}$. Understanding adult vaccination in urban, lower-socioeconomic settings: influence of physician and prevention systems. Ann Fam Med. 2009;7(6):534-541.

19. DeVoe JE, Tillotson CJ, Wallace LS. Children's receipt of health care services and family health insurance patterns. Ann Fam Med. 2009;7(5):406-413.

20. Guendelman S. Health care reform should consider the same health plan for children and their parents [eletter]. http://www. annfammed.org/cgi/eletters/7/5/406\#11312, 13 Oct 2009.

21. Saxon D, Shah A, Oyer DS. Quantitative assessment of diabetic peripheral neuropathy with use of the clanging tuning fork test. Endocrine Pract. 2007;13(1):5-10.

22. Dros J, Wewerinke A, Bindels PJ, van Weert HC. Accuracy of monofilament testing to diagnose peripheral neuropathy: a systematic review. Ann Fam Med. 2009;7(6):555-558

23. Scherger JE. The intellectual basis of family medicine advanced [eletter]. http://www.annfammed.org/cgi/eletters/7/5/387\#11314, 13 Oct 2009.

24. Green LA. Welcomed language and logic [eletter]. http://www. annfammed.org/cgi/eletters/7/5/387\#11302, 2 Oct 2009.

25. Stange KC, Ferrer RL, Miller WL. Making sense of health care transformation as adaptive-renewal cycles. Ann Fam Med. 2009; $7(6): 484-487$

26. MacKenzie JO. Levels of care are developmental levels within the holon [eletter]. http://www.annfammed.org/cgi/eletters/ 7/5/387\#11316, 14 Oct 2009

27. Katerndahl D. Competition and cooperation to optimize the health care [eletter]. http://www.annfammed.org/cgi/eletters/ 7/5/387\#11273, 22 Sep 2009.

28. Stange KC, Ferrer RL, Miller WL. Making sense of health care transformation as adaptive-renewal cycles. Ann Fam Med. 2009, $7(6): 484-487$.

\section{CORRECTION}

Ann Fam Med 2009;8:84. doi:10.1370/afm.1081.

Re: Bennett IM, Baylson M, Kalkstein K, Gillespie G, Bellamy SL, Fleischman J. Early abortion in family medicine: clinical outcomes. Ann Fam Med. 2009; 7(6):527-533.

The rate of successful uncomplicated aspiration abortion reported in the abstract was inadvertently switched with the rate of successful aspiration abortion (including complications). The correct rate should be $96.5 \%$ $(95.5 \%-97.1 \%$,$) as listed in Table 2$. In addition, in the Results section of the text, the rate of successful uncomplicated abortion should be $96.5 \%$, not $96.2 \%$ 